\title{
Chitinolytic assay of indigenous Trichoderma isolates collected from different geographical locations of Chhattisgarh in Central India
}

\author{
Toshy Agrawal* and Anil S Kotasthane
}

\begin{abstract}
Chitin is the second most abundant polymer in nature after cellulose and plays a major role in fungal cell walls. As a producer of variety of chitinase enzymes Trichoderma has become an important means of biological control of fungal diseases. A simple and sensitive method based on the use of basal medium with colloidal chitin as sole carbon source supplemented with Bromo cresol purple ( $\mathrm{pH}$ indicator dye) is proposed to evaluate large populations of Trichoderma for chitinase activity. The soluble substrate with pH indicator dye (Bromo cresol purple, BCP) for the assay of chitinase activity on solid media is sensitive, easy, reproducible semi-quantitative enzyme diffusion plate assay and economic option to determine chitinases. Colloidal chitin derived from Rhizoctonia cell wall and commercial chitin included as a carbon source in broth also allowed selection and comparison of chitinolytic and exochitinase activity in Trichoderma spectrophotometrically. Released N-acetyl- $\beta$-D-glucosamine (NAGA) ranged from 37.67 to $174.33 \mathrm{mg} / \mathrm{ml}$ and 37.67 to $327.67 \mathrm{mg} / \mathrm{ml}$ and p-nitrophenol (pNP) ranged from 0.17 to $35.78 \times 10^{-3} \mathrm{U} / \mathrm{ml}$ and 0.62 to $32.6 \times 10^{-3} \mathrm{U} / \mathrm{ml}$ ) respectively with Rhizoctonia cell wall and commercial chitin derived colloidal chitin supplemented broth.
\end{abstract}

Keywords: Bromo cresol purple, Chitin, N-acetyl- $\beta$-D-glucosamine, p-nitrophenol, Trichoderma, Volume activity

\section{Background}

Efficient bio-control strains of the genus Trichoderma are being developed as promising biological fungicides and their weaponry for this function also includes secondary metabolites with potential applications as novel antibiotics (André \& Monika 2010). They are well known producer of chitinolytic enzymes and used commercially as a source of these proteins. Additional interest in these enzymes is stimulated by the fact that chitinolytic strains of Trichoderma are among the most effective agents of biological control of plant diseases (Harman et al. 1993; Samuels 1996; Spiegel \& Chet 1998; Kubicek et al. 2001; Viterbo et al. 2002; Benitez et al. 2004; Navazio et al. 2007; Goswami et al. 2008; Vinale et al. 2009; Karlsson et al. 2010). Chitinases are chitin-degrading enzymes that hydrolyze the $\beta-1$, 4glycosidic bonds between the $\mathrm{N}$-acetyl glucosamine residues of chitin and are widely distributed in nature (Kitamura \& Kamei 2003). Trichoderma chitinases

\footnotetext{
* Correspondence: toshy@rediffmail.com

Department of Plant Molecular Biology and Biotechnology, Indira Gandhi Krishi Vishwavidyalaya, Raipur 492 006, Chhattisgarh, India
}

belong to the glycosyl hydrolase family 18 and can be further grouped into class III and class V. Many chitinase genes from Trichoderma have been studied and several laboratories around the world are applying these genes to a variety of bio-control strategies and studying the mechanism of fungal antagonism and mycoparasitism (Markovich \& Kononova 2003; Duo-Chuan 2006). For the evaluation of chitinases, insoluble substrates such as tritiated solid chitin, colloidal chitin or chitin covalently coupled to different dyes (chitin red, chitinazure) can be used. In accordance with the substrate used, the assays are radiometric or photometric. A typical method to evaluate chitinases involves colorimetric quantification (Monreal \& Reese 1969) which is timeconsuming, less sensitive and not easily applicable to identify poor-chitinolytic microbial strains. Therefore, more simple and rapid assays like colloidal chitin (major carbon source) supplemented in solid basal media resulting in clear halo of chitin-digestion and of the microbial colonies which are measures of the chitinase activity Rojas Avelizapa et al. (2001) are used. However, this method also has a low sensitivity and its results depend 
on concentration and size of the particles of colloidal chitin, thickness of the media and amount and kind of inoculums. More sensitive techniques require more expensive substrates, which are suitable to study specificity of chitinases more than to select chitinolytic strains (O'Brien \& Collwell 1987; McCreath \& Gooday 1992; Fra"ndberg \& Schnu“rer 1994; Barboza Corona et al. 1999). Agrawal and Kotasthane (Agrawal \& Kotasthane 2009) proposed a sensitive, easy, reproducible and economic option to determine chitinases (available via Dialog, http://www.isth.info/ methods/method.php?method_id=11 ) which was also followed by Kamala and IndiraDevi (Kamala \& IndiraDevi 2011; Kamala \& IndiraDevi 2012) to evaluate the chitinolytic properties of Trichoderma isolates from Manipur (North-East India) against Pythium aphanidermatum, Fusarium oxysporum and Rhizoctonia solani.

Present study describes the screening chitinase activity of Trichoderma isolates using two different chitin sources (colloidal chitin derived from Rhizoctonia cell wall and commercial chitin) using the simple media supplemented with bromocresol purple (Agrawal \& Kotasthane 2009). Screened Trichoderma isolates were also assessed spectrophotometrically for N-acetyl- $\beta$ D-glucosamine (NAGA) (for total chitinolytic activity) and p-nitrophenol (pNP) (for exochitinase activity) from colloidal chitin supplemented in broth.

\section{Results and discussion}

\section{Dyeing of basal chitinase detection medium}

Basal chitinase detection medium was directly supplemented with colloidal chitin $(4.5 \mathrm{~g} / \mathrm{l})$ and bromocresol purple $(0.15 \mathrm{~g} / \mathrm{l})$. Resulting substrate had a bright yellowcolor, and retained enough bromocresol purple even after $\mathrm{pH}$ was adjusted to 4.7 and sterilization at $121^{\circ} \mathrm{C}$ for $15 \mathrm{~min}$ (Figure 1). No complicated protocols for dyeing of the chitinous material and mordant to fix colors were required as per previous reports (Go'mez et al. 2004; (Fen et al. 2006; Wirth \& Wolf 1990)).

Separated polysaccharide molecules of hydrochloric acid induced colloidal chitin may therefore, form the basis for hydrogen bonds formation between the chitinous matrix and the dye. Chitobiose, as a minimal repeating unit of chitin is formed by two NAGA molecules linked by a $\beta-1,4$ glycosidic unions and, in every NAGA residue, there are two hydroxyls, one carbonyl and one imine exposed groups that may acts as a reactive binding site for anionic dyes such as bromocresol purple to produce a color-bound complex (Yellow).

Determination of chitinase activity of trichoderma isolates on colloidal chitin supplemented medium

Colloidal chitin media containing bromocresol purple $(\mathrm{pH}$ 4.7) when inoculated with chitinolytic Trichoderma, resulted in breakdown of chitin into $\mathrm{N}$ - acetyl glucosamine causing a

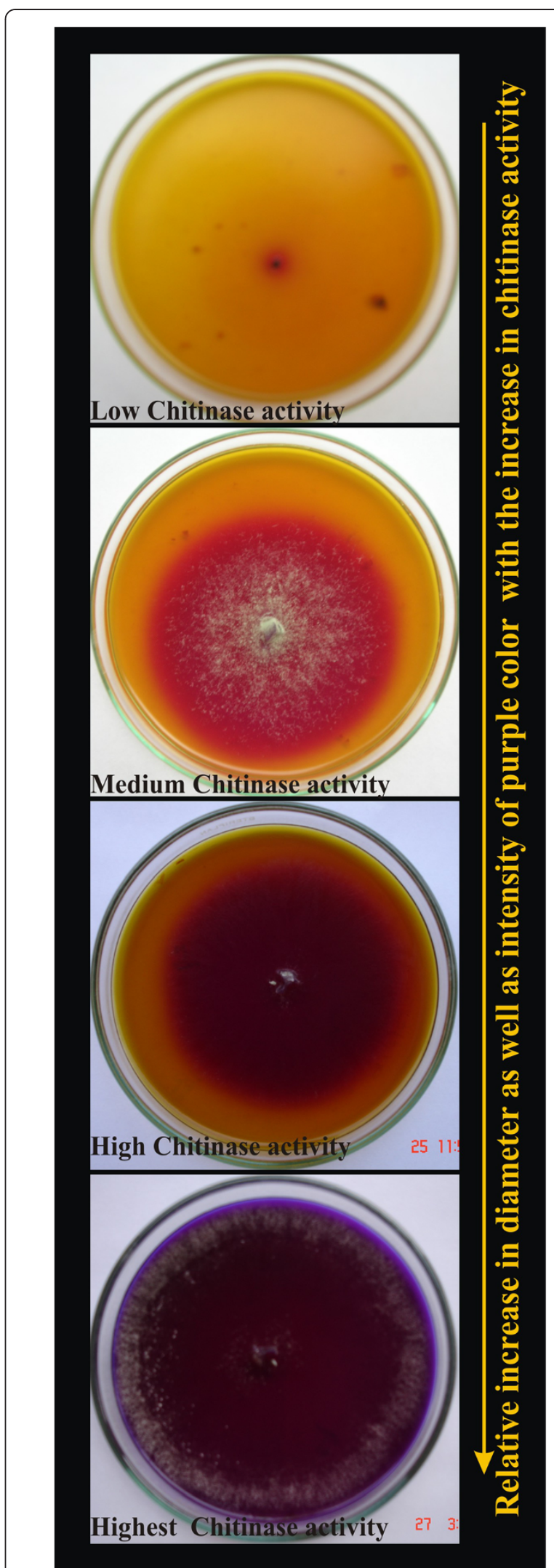

Figure 1 Screening of Trichoderma isolates for chitinase activity on medium supplemented with colloidal chitin. 
corresponding shift in $\mathrm{pH}$ towards alkalinity and change of color of $\mathrm{pH}$ indicator dye (BCP) from yellow to purple zone surrounding the inoculated fresh culture plugs in the region of chitin utilization (Figure 1). Chitinase activity exhibited by 61 isolates of Trichoderma was determined by the diameter of the purple colored zone after 3 days of incubation in the colloidal chitin supplemented agar medium and were classified into different groups (1=no chitinase activity; $2=$ low chitinase activity; $3=$ medium chitinase activity and 4=high chitinase activity) (Table 1). Seventeen isolates( \# 4, 27, 73, 75, 85, 97, 99, 152, 217, 238, 249, 261, cb4, Gv, Th1, $\operatorname{Tv}(t)$ and 231a) gave rapid and highest response in both types of colloidal chitin (derived from Rhizoctonia cell wall and commercial chitin) and represented high chitinase activity group(s). Eight (\#2, 10, 29, 32, 43, 53, 55, 204) and twelve isolates (\#6, 20, 25, 62, 93, 98, 106, 120, 211, 226, 297 and 233b) expressed low and medium chitinase activity respectively. No detectable purple colored zone was observed with isolate \#111 on any of the colloidal chitin (derived from

Table 1 Screening of Trichoderma isolates for Chitinase production on solid medium supplemented with colloidal chitin derived from Rhizoctonia cell wall (RCW) and commercial chitin (Cc)

Trichoderma isolates showing similar chitinase activity on RCW and Cc derived colloidal chitin

\begin{tabular}{lllll}
\hline Isolate Group & NIL & Low & Medium & High \\
\hline A & - & 10,32 & $6,20,25,211,120$ & Th1, TV(t), 73, 217, 4 \\
\hline B & - & 43,29 & - & 27 \\
\hline C & - & 55 & $62,98,297$ & GV, 231a, 238, 249 \\
\hline $\mathbf{D}$ & - & - & 93,226 & $85,99,152,261$ \\
\hline E & - & 2,53 & - & Cb4, 75, 97 \\
\hline F & 111 & 204 & $106,233 b$ & - \\
\hline
\end{tabular}

Isolate Group Low / Medium preference for Cc derived colloidal chitin but Medium / High preference for RCW derived colloidal chitin

\begin{tabular}{ll}
\hline $\mathbf{A}$ & 14,207 \\
\hline $\mathbf{B}$ & 24 \\
\hline $\mathbf{C}$ & $48,107,38$ \\
\hline $\mathbf{D}$ & $145 b 1,326$ \\
\hline $\mathbf{E}$ & - \\
\hline $\mathbf{F}$ & $40(1) b, 91,8$ \\
\hline
\end{tabular}

Isolate Group Low / Medium preference for RCW derived colloidal chitin but Medium / High preference for Cc derived colloidal chitin

\begin{tabular}{ll}
\hline $\mathbf{A}$ & 68,1 \\
\hline $\mathbf{B}$ & 28 \\
\hline $\mathbf{C}$ & 12,202 \\
\hline $\mathbf{D}$ & 173 \\
\hline $\mathbf{E}$ & 46,102 \\
\hline $\mathbf{F}$ & $114,243,332,125 \mathrm{~b}$ \\
\hline
\end{tabular}

$\mathrm{A}=T$. harzianum / viride; $\mathrm{B}=T$. citirinoviride; $\mathrm{C}=T$ aureoviride; $\mathrm{D}=T$. virens; $\mathrm{E}=$ Isolates belonging to Sec. Longibrachiatum; $\mathrm{F}=$ Isolates belonging to Sec. Pachybasium.
Rhizoctonia cell wall and commercial chitin) supplemented medium. Variable preference for media supplemented with commercial chitin (Cc) (Himedia) and Rhizoctonia cell wall (RCW) derived colloidal chitin was observed among the isolates (Table 1). Trichoderma isolates (\# 14, 48, 107, 326, 145b1, 40 (Agrawal \& Kotasthane 2009)b, 91, 207, 24, 8, 38) showed less preference for chitinase activity on media supplemented with commercial chitin derived colloidal chitin and expressed medium / high chitinase activity on Rhizoctonia cell wall derived colloidal chitin whereas isolates \# 12, 28, 46, 68, 4, 102, 125b, 114, 173, 202, 243, 332 expressed medium / high chitinase activity on media supplemented with colloidal chitin derived from commercial chitin but expressed low / medium chitinase activity on substrate supplemented with Rhizoctonia cell wall derived colloidal chitin (Table 1).

Bromocresol Purple (BCP or 5,5"-dibromo-o-cresolsulfophthalein $\mathrm{pKa}$ 6.3), is a halo chromic chemical compound which causes the color of the solution to change depending on the $\mathrm{pH}$ and therefore is used to determine $\mathrm{pH}$ (acidity or basicity) of the substrate visually. Bromocresol Purple is a detector for hydronium ions $\left(\mathrm{H}_{3} \mathrm{O}^{+}\right)$or hydrogen ions $\left(\mathrm{H}^{+}\right)$in the Arrhenius model. For $\mathrm{pH}$ indicators that are weak proteolytes, the Henderson-Hasselbalch equation derived from the acidity constant, states that when $\mathrm{pH}$ equals the $\mathrm{pKa}$ value of the indicator, both species are present in 1:1 ratio. If $\mathrm{pH}$ is above the $\mathrm{pKa}$ value, the concentration of the conjugate base is greater than the concentration of the acid, and the color associated with the conjugate base dominates. If $\mathrm{pH}$ is below the $\mathrm{pKa}$ value, the converse is true.

Usually, the color change is not instantaneous at the $\mathrm{pKa}$ value, but there is a $\mathrm{pH}$ range where a mixture of colors is present. This $\mathrm{pH}$ range falls between the $\mathrm{pKa}$ value plus or minus one. If the concentration of the conjugate base ( $\mathrm{N}$-acetyl glucosamine $+\mathrm{BCP})$ is ten times greater than the concentration of the acid, their ratio is 10:1, and consequently the $\mathrm{pH}$ is $\mathrm{pKa}+1$. Conversely, if there is a tenfold excess of the acid (Colloidal chitin $+\mathrm{BCP}$ supplemented acidic media) with respect to the base, the ratio is $1: 10$ and the $\mathrm{pH}$ is $\mathrm{pKa}-1$. Chitin agar plate has been used earlier for isolating chitinolytic microorganisms and observing clear zone around the colony of microorganisms ((Wirth \& Wolf 1990; Cody 1989); Rojas Avelizapa et al. 2001). Previous attempt to synthesize a remazol brilliant blue (RBB) derivative of chitosan resulted in a relatively poorly soluble polymer (Fen et al. 2006) which rendered difficult its application to direct screening of microbial colonies on agar media but soluble RBB-chitosan (lower molecular weight derivative) was particularly suitable for the detection of chitosanase positive organisms on agar media (Brzezinski et al. 2010). However, these methods 
have low sensitivity and its results depend on concentration and size of the particles of colloidal chitin, thickness of the media and the amount and kinds of inoculum. Glycol chitin and indicators such as Calcoflour White M2R, Flourescein isothiocyanate, Rhodamine B etc. to screen hyperchitinase producing bacteria and fungus has been reported by (Vaidya et al. 2003). More sensitive techniques require more expensive substrates, which are suitable to study specificity of chitinases more than to select chitinolytic strains (O'Brien \& Collwell 1987; McCreath \& Gooday 1992; Fra"ndberg \& Schnu"rer 1994; Barboza Corona et al. 1999). The evaluation of chitinases using $\mathrm{pH}$ indicator dye bromocresol purple as proposed by Agrawal and Kotasthane (Agrawal \& Kotasthane 2009) (available via Dialog, http://www.isth.info/methods/method.php? method_id=11. Posted on 2009-08-04 at ISTH) has the following advantages: (A) the soluble substrate with $\mathrm{pH}$ indicator dye (BCP) for the assay of chitinase activity on solid media is sensitive, easy, reproducible semiquantitative enzyme diffusion plate assay and economic option to determine chitinases. (B) its preparation is easy and inexpensive; $(\mathrm{C})$ the possibility of interference of $\mathrm{BCP}$ is minimal under the environmental conditions used ordinarily in the chitinase assays; (E) as colloidal chitin (CC)-BCP is not toxic for microorganisms, it can be added simultaneously as a carbon source and as a chitinase inducer in the culture media. This fact allows a simpler, fast and accurate one-step process for the selection of chitinolytic microorganisms and was therefore also followed by Kamala and IndiraDevi (Kamala \& IndiraDevi 2011; Kamala \& IndiraDevi 2012) to evaluate the chitinolytic properties of Trichoderma isolates from Manipur (NorthEast India) against Pythium aphanidermatum, Fusarium oxysporum and Rhizoctonia solani.

\section{Spectrophotometric determination of chitinase activity of Trichoderma isolates Total chitinolytic activity}

Total chitinolytic activity was assayed by measuring the release of reducing saccharides from colloidal chitin. Standard curve generated with $\mathrm{N}$-acetyl- $\beta$-D-glucosamine (NAGA) was used to determine reducing saccharide concentration. Chitinolytic activity was expressed in terms of the concentration of NAGA $(\mathrm{mg} / \mathrm{ml})$ released in colloidal chitin (derived from Rhizoctonia cell wall and commercial chitin) supplemented media. Released NAGA concentration ranged from 37.67 (isolate \#10) to 174.33 (isolate \#145b1) $\mathrm{mg} / \mathrm{ml}$ and 37.67 (isolate \#10) to 327.67(isolate \#85) $\mathrm{mg} / \mathrm{ml}$ in Rhizoctonia cell wall and commercial chitin derived colloidal chitins respectively (Table 2; Figure 2A).

Amount of released NAGA $(\mathrm{mg} / \mathrm{ml})$ in colloidal chitin supplemented media by individual isolates of Trichoderma spp. formed the basis to categorize them in 1)
Low (NAGA conc. $30-60 \mathrm{mg} / \mathrm{ml}$ ) 2) Medium (NAGA conc. $61-80 \mathrm{mg} / \mathrm{ml}$ ) and 3) High (NAGA conc. $81 \mathrm{mg} / \mathrm{ml}$ and above) chitinase producers. Three isolates (\#38, Cb4 and 202) were identified as high chitinase producers where as seven isolates belonged to each low $(\# 1,6,10$, $14,28,43$ and 91) and medium (\#97, 111, 152, 173, 211, 261 , and Gv) chitinase activity groups. The isolates expressed differential chitinase activity on media supplemented with Rhizoctonia cell wall and commercial chitin derived colloidal chitins. Commercial chitin derived colloidal chitin supplemented broth was less preferred chitin source (by only 14 isolates) as compared to Rhizoctonia cell wall derived chitin which was more potent in inducing total chitinolytic response in 30 isolates Trichoderma spp. Fourteen Trichoderma isolates expressed higher preference and an increased release of NAGA (medium / high chitinase) on media supplemented with colloidal chitin derived from commercial chitin than Rhizoctonia cell wall derived colloidal chitin (Table 3).

\section{Exochitinase activity}

Similarly, exochitinase activity ( $\mathrm{N}$-acetyl- $\beta$-D-glucosaminidase) was measured as release of p-nitrophenol (pNP) from $\mathrm{p}$-nitrophenyl- $\mathrm{N}$-acetyl- $\beta$-D-glucosaminide (pNPg) The volume activity of pNP ranged from 0.17 to $35.78 \mathrm{X}$ $10^{-3} \mathrm{U} / \mathrm{ml}$ and 0.62 to $32.6 \times 10^{-3} \mathrm{U} / \mathrm{ml}$ in Rhizoctonia cell wall and commercial chitin derived colloidal chitins respectively. Minimum volume activity of pNP was observed to be $0.17 \times 10^{-3} \mathrm{U} / \mathrm{ml}$ for the isolate \#12 and $0.62 \times 10^{-3} \mathrm{U} / \mathrm{ml}$ for the isolate \#207 respectively in Rhizoctonia cell wall and commercial chitin derived colloidal chitins whereas maximum was for isolates \#202 and \#261 respectively (Table 2; Figure 2B).

Volume activity of pNP formed the basis to establish exochitinase activity in the reaction mixture and the differential responses exhibited by different isolates were broadly categorized as 1 ) Low (Volume activity $\mathrm{U} / \mathrm{ml} 0.1$ to $7.0 \mathrm{X} \mathrm{10^{-3 }}$ ) 2) Medium (Volume activity U/ml 7.1 to 17 $\mathrm{X} 10^{-3}$ ) and 3) High (Volume activity U/ml $17 \times 10^{-3}$ and above). Seven isolates (\# 62, 202, 48, 152, 326, 145b1, 261) were identified as high chitinase producers where as sixteen (\# 1, 6, 10, 25, 27, 55, 68, 73, 91, 97, 106, 120, 207, 211, 332, Th1 ) and three (\#107, 53, 40 (Agrawal \& Kotasthane 2009)b) isolates belonged to low and medium chitinase activity groups. The isolates expressed differential chitinase activity on media supplemented with Rhizoctonia cell wall and commercial chitin derived colloidal chitins Sixteen Trichoderma isolates showed higher preference and expressed medium / high chitinase activity on Rhizoctonia cell wall derived colloidal chitin whereas Trichoderma 19 isolates expressed higher preference and an increased volume activity (medium / high chitinase) on media supplemented with colloidal chitin derived from commercial chitin (Table 4). 
Table 2 Spectrophotometric determination of Chitinolytic and Exochitinase activity of Trichoderma isolates in media supplemented with colloidal chitin derived from Rhizoctonia cell wall (RCW) and Commercial chitin (Cc)

\begin{tabular}{|c|c|c|c|c|}
\hline \multirow[t]{2}{*}{ Isolate No. } & \multicolumn{2}{|c|}{ NAGA conc. (mg/ml) } & \multicolumn{2}{|c|}{ Volume activity $\left(\mathrm{U} / \mathrm{ml} \mathrm{X} 10^{-3}\right)$} \\
\hline & RCW & Cc & RCW & Cc \\
\hline \multicolumn{5}{|c|}{ GROUP A (T. harzianum / viride) } \\
\hline 1 & 57.67 & 54.33 & 4.26 & 4.54 \\
\hline 4 & 51 & 111 & 4.26 & 17.89 \\
\hline 6 & 41 & 41 & 6.82 & 6.76 \\
\hline 10 & 37.67 & 37.67 & 1.99 & 6.65 \\
\hline 14 & 51 & 47.67 & 3.69 & 7.04 \\
\hline 20 & 74.33 & 91 & 33.17 & 3.41 \\
\hline 25 & 87.67 & 61 & 4.66 & 5.62 \\
\hline 32 & 74.33 & 104.33 & 34.02 & 5.85 \\
\hline 68 & 44.33 & 64.33 & 1.25 & 2.95 \\
\hline 73 & 127.67 & 77.67 & 2.84 & 3.12 \\
\hline 120 & 91 & 57.67 & 2.10 & 5.57 \\
\hline 207 & 67.67 & 54.33 & 2.89 & 0.63 \\
\hline 211 & 64.33 & 71 & 1.31 & 1.76 \\
\hline 217 & 64.33 & 37.67 & 9.09 & 1.48 \\
\hline Th1 & 74.33 & 84.33 & 0.63 & 1.19 \\
\hline $\mathrm{Tv}(\mathrm{t})$ & 71 & 54.33 & 4.89 & 7.1 \\
\hline \multirow[t]{2}{*}{ Mean } & 67.46 & 65.58 & 7.37 & 5.09 \\
\hline & $(5.59)$ & $(5.66)$ & $(2.62)$ & $(1.02)$ \\
\hline $\bar{P}$ & \multicolumn{2}{|c|}{$0.4837^{\text {ns }}$} & \multicolumn{2}{|c|}{$0.0004^{5}$} \\
\hline \multicolumn{5}{|c|}{ Group B (T. citirinoviride) } \\
\hline 24 & 61 & 57.67 & 13.52 & 20.51 \\
\hline 27 & 47.67 & 61 & 1.36 & 2.73 \\
\hline 28 & 57.67 & 54.33 & 9.26 & 27.83 \\
\hline 29 & 67.67 & 141 & 5.96 & 12.49 \\
\hline 43 & 57.67 & 54.33 & 14.37 & 3.41 \\
\hline \multirow[t]{2}{*}{$\overline{\text { Mean }}$} & 58.34 & 73.67 & 8.89 & 13.39 \\
\hline & $(3.23)$ & $(16.88)$ & $(2.42)$ & $(4.86)$ \\
\hline$P$ & \multicolumn{2}{|c|}{$0.0037^{5}$} & \multicolumn{2}{|c|}{$0.102^{\text {ns }}$} \\
\hline
\end{tabular}

Group C ( $T$. aureoviride)

\begin{tabular}{lcccc}
\hline 12 & 81 & 54.33 & 0.17 & 18.80 \\
\hline 38 & 81 & 114.33 & 22.44 & 1.76 \\
\hline 48 & 67.67 & 51 & 35.16 & 27.21 \\
\hline 55 & 81 & 61 & 2.49 & 4.88 \\
\hline 62 & 71 & 47.67 & 33.06 & 18.69 \\
\hline 98 & 101 & 61 & 17.44 & 1.25 \\
\hline 107 & 84.33 & 41 & 8.69 & 8.80 \\
\hline 202 & 87.67 & 107.67 & 35.78 & 22.15 \\
\hline 249 & 81 & 51 & 13.18 & 0.85 \\
\hline 297 & 77.67 & 51 & 3.35 & 21.24 \\
\hline $231 a$ & 87.67 & 64.33 & 15.90 & 27.38 \\
\hline Gv & 74.33 & 61 & 12.89 & 24.77 \\
\hline
\end{tabular}

Table 2 Spectrophotometric determination of Chitinolytic and Exochitinase activity of Trichoderma isolates in media supplemented with colloidal chitin derived from Rhizoctonia cell wall (RCW) and Commercial chitin (Cc) (Continued)

\begin{tabular}{lcccc}
\hline Mean & 81.28 & 63.78 & 16.71 & 14.82 \\
\cline { 2 - 5 } & $(2.51)$ & $(6.66)$ & $(3.64)$ & $(3.04)$ \\
\hline$P$ & \multicolumn{2}{c}{$0.0015^{5}$} & \multicolumn{3}{c}{$0.2799^{\text {ns }}$} \\
\hline Group D (T. virens) & \multicolumn{3}{c}{} \\
\hline 85 & 61 & 327.67 & 9.88 & 19.54 \\
\hline 93 & 64.33 & 154.33 & 30.33 & 14.26 \\
\hline 99 & 64.33 & 234.33 & 0.68 & 12.55 \\
\hline 152 & 77.67 & 71 & 34.76 & 19.09 \\
\hline 173 & 71 & 77.67 & 9.43 & 19.77 \\
\hline 226 & 64.33 & 107.67 & 23.57 & 15.62 \\
\hline 261 & 71 & 77.67 & 30.16 & 32.60 \\
\hline 326 & 61 & 94.33 & 26.18 & 19.82 \\
\hline $145 b 1$ & 174.33 & 64.33 & 22.38 & 23.69 \\
\hline Mean & 78.78 & 134.33 & 20.82 & 19.66 \\
\hline$P$ & $0.0091^{5}$ & & $0.0282^{5}$ \\
\hline
\end{tabular}

\section{Group E (Isolates of Sec.L ongibrachiatum)}

\begin{tabular}{lcccc}
\hline $\mathrm{Cb} 4$ & 84.33 & 81 & 20.85 & 14.88 \\
\hline 2 & 91 & 61 & 5.62 & 16.36 \\
\hline 46 & 84.33 & 54.33 & 23.69 & 10.51 \\
\hline 53 & 84.33 & 51 & 7.61 & 14.77 \\
\hline 75 & 81 & 57.67 & 19.31 & 13.69 \\
\hline 97 & 74.33 & 64.33 & 2.73 & 1.48 \\
\hline 102 & 84.33 & 61 & 35.5 & 15.68 \\
\hline Mean & 83.38 & 61.48 & 16.47 & 12.48 \\
\cline { 2 - 5 } & $(1.89)$ & $(3.67)$ & $(4.44)$ & $(1.96)$ \\
\hline P & \multicolumn{3}{c}{$0.065^{\text {ns }}$} & \multicolumn{3}{c}{$0.0342^{5}$} \\
\hline
\end{tabular}

\section{Group F (Isolates of Sec. Pachybasium)}

\begin{tabular}{lcccc}
\hline 8 & 74.33 & 94.33 & 4.71 & 13.41 \\
\hline 91 & 47.67 & 51 & 0.45 & 0.91 \\
\hline 106 & 67.67 & 54.33 & 1.54 & 2.61 \\
\hline 111 & 77.67 & 74.33 & 25.28 & 7.78 \\
\hline 114 & 71 & 101 & 1.82 & 8.41 \\
\hline 204 & 114.33 & 61 & 12.16 & 5.79 \\
\hline 238 & 87.67 & 57.67 & 1.02 & 7.89 \\
\hline 243 & 91 & 51 & 24.31 & 13.41 \\
\hline 332 & 87.67 & 57.67 & 0.34 & 1.42 \\
\hline $125 b$ & 94.33 & 61 & 5.79 & 9.09 \\
\hline $233 b$ & 77.67 & 57.67 & 5.62 & 21.87 \\
\hline $40(1) b$ & 74.33 & 47.67 & 13.92 & 9.71 \\
\hline Mean & 80.45 & 64.06 & 8.08 & 8.53 \\
\cline { 2 - 5 } & $(4.75)$ & $(4.95)$ & $(2.56)$ & $(1.69)$ \\
\hline$P$ & $0.4463^{\text {ns }}$ & & $0.0886^{\text {ns }}$ \\
\hline Figures nar & & &
\end{tabular}

Figures in parenthesis represent standard error.

${ }^{s}=$ significant $(P$-value $<0.05) ;{ }^{n s}=$ non-significant $(P$-value $>0.05)$. 

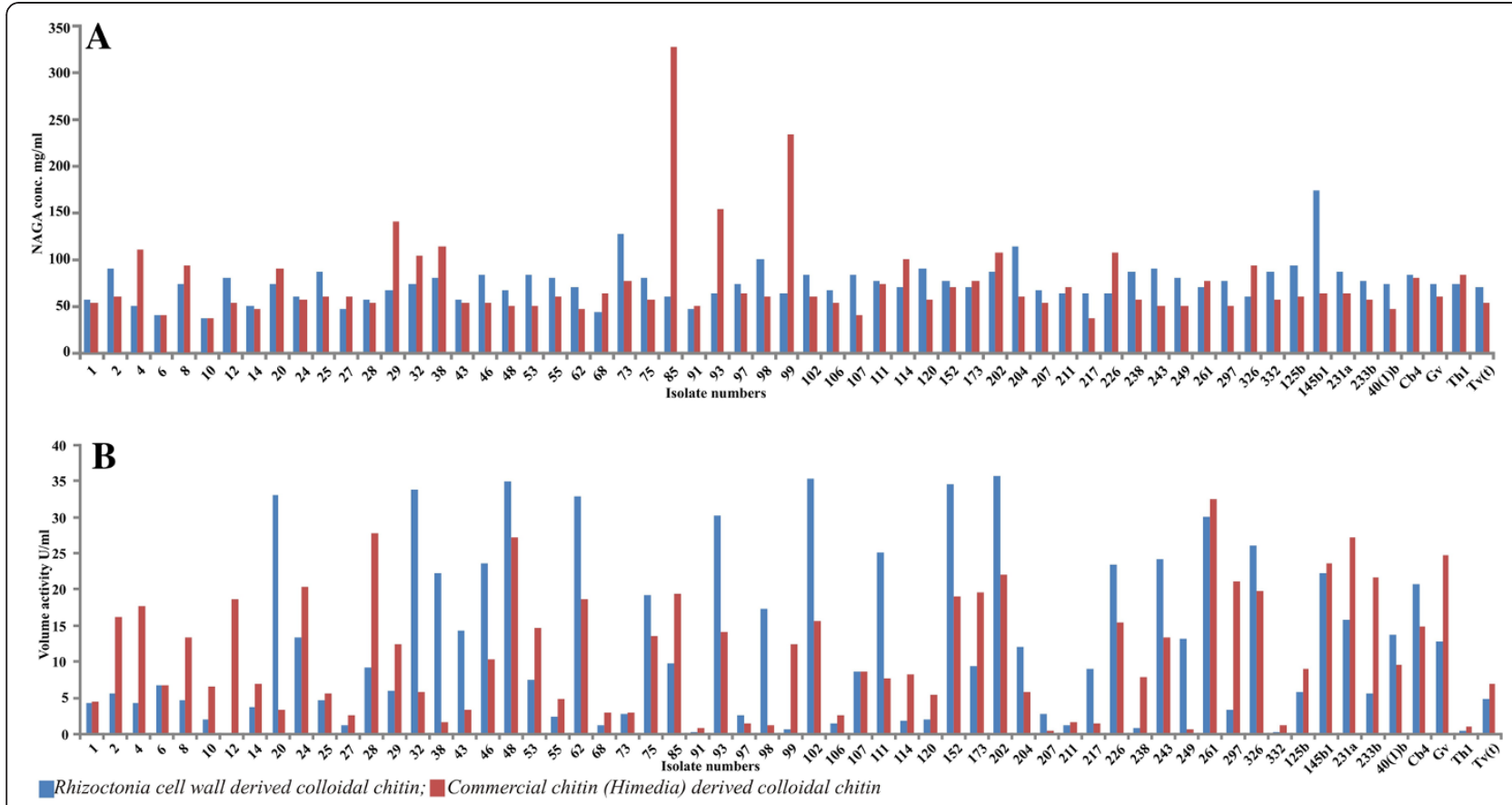

Figure 2 A. Chitinolytic activity of culture filtrates of Trichoderma isolates grown on broth medium supplemented with Rhizoctonia cell wall and Commercial chitin derived colloidal chitin. B. Exochitinase activity of culture filtrates of Trichoderma isolates grown on broth medium supplemented with Rhizoctonia cell wall and Commercial chitin derived colloidal chitin.

Three isolates of Trichoderma spp. (\#38, Cb4 and 202) were identified as high for total chitinolytic activity and seven isolates (\# 62, 202, 48, 152, 326, 145b1, 261) were identified as high exochitinase ( $\mathrm{N}$-acetyl- $\beta$ - $\mathrm{D}$-glucosaminidase) producers following spectrophotometric determination. Isolates \# Cb4, 152, 261 were also identified as high chitinase producers on solid medium. Chitinase activity of Trichoderma isolates as determined in plates and by spectrophotometric assay is not always in agreement with the information obtained in a secondary screening/ spectrophotometric assays. It was observed that the isolates with poor or low chitinase activity in solid medium showed medium or high chitinolytic and / or volume activity spectrophotometrically. This disagreement in preliminary data and secondary screening might be due to the quantitative evaluations of the enzyme secreted by every strain in a liquid medium, along different times of incubation. In addition, assays using different dilutions of the samples are required when the level of the enzyme is high, or extending the time of incubation if the amount of enzyme is low. The results of total chitinolytic activity assayed by measuring the release of $\mathrm{N}$-acetyl- $\beta-\mathrm{D}$-glucosamine (reducing saccharides) from colloidal chitin and $\mathrm{N}$-acetyl- $\beta$-D-glucosaminidase (exochitinase) activity measured as release of $\mathrm{p}$-nitrophenol ( $\mathrm{pNP}$ ) from $\mathrm{p}$-nitrophenyl-N-acetyl- $\beta$-Dglucosaminide (pNPg) are in agreement with those of (El-Katatny et al. 2000), Tweddell et al. (Tweddell et al.
1994) and Calistru et al. (1997) who reported the use of crude culture filtrates of $T$. harzianum possessing $\beta-1,3-$ glucanase and chitinase activities. It revealed the ability to release reducing sugars (glucose, GlcNAc) from dried or fresh mycelium of the phytopathogenic fungus $S$. rolfsii. Harman et al. (1993) measured and monitored chitinase activity spectrophotometrically as the release of the p-nitrophenol (pNP) from p-nitrophenyl-N-acetyl-D-glucosaminide. The observations of the present investigation are supported by those reported by De la Cruz et al. (1992) and Lorito et al. (1994a) that the production of the hydrolytic enzymes has been affected by culture conditions and by the host. The production of extracellular chitinases and ß-glucanases was produced in the presence of phytopathogen cell walls as carbon source, suggesting that these substrate can also act as inducers of the synthesis of the lytic enzymes.

\section{Conclusions}

The results of this study clearly show that large inter strain and inter species differences exist in both total chitinolytic and exochitinase activity of Trichoderma isolates. However, there appears to be no common pattern of chitinase activity in the media supplemented with Rhizoctonia cell wall and commercial chitin derived colloidal chitin. Some isolates, e.g. T. harzianum/viride (\#20 \& 32) and T. aureoviride (\#38, 98 \& 249) showed highest exochitinase activity whereas $T$. aureoviride (\#12, 
Table 3 Chitinolytic activity of culture filtrates of Trichoderma isolates grown on media (broth) supplemented with colloidal chitin derived from Rhizoctonia cell wall (RCW) and Commercial chitin (Cc)

Trichoderma isolates showing similar Chitinolytic activity (NAGA conc.)

\begin{tabular}{llll}
\hline Isolate Group & Low & Medium & High \\
\hline $\mathbf{A}$ & $1,6,10,14$ & 211 & - \\
\hline $\mathbf{B}$ & 28,43 & - & - \\
\hline $\mathbf{C}$ & - & $\mathrm{GV}$ & 38,202 \\
\hline $\mathbf{D}$ & - & 152,261173 & - \\
\hline $\mathbf{E}$ & - & 97 & $\mathrm{Cb} 4$ \\
\hline $\mathbf{F}$ & 91 & 111 & - \\
\hline
\end{tabular}

Isolate Group Low / Medium preference for Cc derived colloidal chitin but Medium / High preference for RCW derived colloidal chitin

\begin{tabular}{|c|c|}
\hline A & $\operatorname{Tv}(\mathrm{t}), 120,217,207,25,73$ \\
\hline$\underline{B}$ & 24 \\
\hline $\mathrm{C}$ & $12,62,48,107,249,297,55,98,231 \mathrm{a}$ \\
\hline$\underline{\mathbf{D}}$ & 145b1 \\
\hline $\mathrm{E}$ & $46,53,75,2,102$ \\
\hline$F$ & 40(1)b, 106, 233b, 238, 243, 332, 125b, 204 \\
\hline Isolate Group & $\begin{array}{l}\text { Low / Medium preference for RCW derived } \\
\text { colloidal chitin but Medium / High preference for } \\
\text { Cc derived colloidal chitin }\end{array}$ \\
\hline
\end{tabular}

\begin{tabular}{ll}
\hline $\mathbf{A}$ & $4,68,20,32$, Th1 \\
\hline $\mathbf{B}$ & 27,29 \\
\hline $\mathbf{C}$ & - \\
\hline $\mathbf{D}$ & $85,93,99,226,326$ \\
\hline $\mathbf{E}$ & - \\
\hline $\mathbf{F}$ & 8,114 \\
\hline
\end{tabular}

Chitinase activity (NAGA conc.) Low $=(30-60 \mathrm{mg} / \mathrm{ml})$; Medium $=(61-80 \mathrm{mg} / \mathrm{ml})$; High $=(81 \mathrm{mg} / \mathrm{ml}$ and above); $A=T$. harzianum / viride; $B=T$. citirinoviride; $C=T$ aureoviride; $D=T$. virens; $E=$ Isolates belonging to Sec. Longibrachiatum; $F=$ Isolates belonging to Sec. Pachybasium.

107 \& 249); isolates of Sec. Longibrachiatum (\#46, 53 \& 75) and isolates of Sec. Pachybasium (\# 238, 243 \& 332) produced highest total chitinolytic activity in medium supplemented with colloidal chitin derived from Rhizoctonia cell wall, while others showed little difference in chitinase activity irrespective of colloidal chitin type. There appears to be no direct relationship between levels of NAGA and pNP produced by individual Trichoderma isolates. For example, T. harzianum/viride isolate \#73 produced one of the highest total chitinase activities (NAGA conc.) recorded but one of the lowest exochitinase activities in medium supplemented with RCW derived colloidal chitin.

In general, Rhizoctonia cell wall derived colloidal chitin was able to induce chitinolytic activity in more number of isolates (38 isolates of Trichoderma spp.) and belonged to medium / high chitinolytic category where as the reaction mixture containing commercial chitin derived colloidal chitin induced total chitinolytic as well as exochitinase activity in 26 isolates of Trichoderma spp. (Table 5). This suggests that there has been a shift in the balance of the organism's metabolic processes towards production of lytic enzymes under these conditions. Sivan and Chet (1989) reported that the production of extracellular $\beta$-(André \& Monika 2010; Agrawal \& Kotasthane 2009)-glucanases, chitinases and proteinase increases significantly when Trichoderma spp. are grown in media supplemented with either autoclaved mycelium or isolated purified host fungal cell walls. Several lines of similar evidences indicate the use of different substrates such as p-nitro phenyl keto oligomers, differentially purified chitins or fungal cell walls, 4-methyl umbelliferil derivatives, blue substrate etc. to assay, purify and characterize chitinolytic enzymes from

\section{Table 4 Exochitinase ( $\mathrm{N}$-acetyl- $\boldsymbol{\beta}-\mathrm{D}$-glucosaminidase)} activity of culture filtrates of Trichoderma isolates grown on media (broth) supplemented with colloidal chitin derived from Rhizoctonia cell wall (RCW) and Commercial chitin (Cc)

Trichoderma isolates showing similar Exochitinase activity (Volume activity)

\begin{tabular}{|c|c|c|c|}
\hline Group & Low & Medium & High \\
\hline A & $\begin{array}{l}\text { 207, Th1, 211, 68, 73, 1, 120, } \\
25,10,6\end{array}$ & - & - \\
\hline B & 27 & - & - \\
\hline$C$ & 55 & 107 & $62,202,48$ \\
\hline $\mathrm{D}$ & - & - & $\begin{array}{l}152,326,145 b 1, \\
261\end{array}$ \\
\hline $\mathrm{E}$ & 97 & 53 & - \\
\hline$F$ & $91,332,106$ & $40(1) \mathrm{b}$ & - \\
\hline $\begin{array}{l}\text { Isolate } \\
\text { Group }\end{array}$ & \multicolumn{3}{|c|}{$\begin{array}{l}\text { Low / Medium preference for Cc derived colloidal } \\
\text { chitin but Medium / High preference for RCW derived } \\
\text { colloidal chitin }\end{array}$} \\
\hline A & \multicolumn{3}{|l|}{$217,20,32$} \\
\hline B & \multicolumn{3}{|l|}{43} \\
\hline $\mathrm{C}$ & \multicolumn{3}{|l|}{$249,98,38$} \\
\hline $\mathrm{D}$ & \multicolumn{3}{|l|}{93,226} \\
\hline $\mathrm{E}$ & \multicolumn{3}{|l|}{$46,75,102, \mathrm{Cb} 4$} \\
\hline$F$ & \multicolumn{3}{|l|}{$204,111,243$} \\
\hline $\begin{array}{l}\text { Isolate } \\
\text { Group }\end{array}$ & \multicolumn{3}{|c|}{$\begin{array}{l}\text { Low / Medium preference for RCW derived colloidal } \\
\text { chitin but Medium / High preference for Cc derived } \\
\text { colloidal chitin }\end{array}$} \\
\hline$A$ & \multicolumn{3}{|l|}{$14,4, \operatorname{Tv}(\mathrm{t})$} \\
\hline $\mathrm{B}$ & \multicolumn{3}{|l|}{$29,28,24$} \\
\hline $\mathrm{C}$ & \multicolumn{3}{|l|}{$12,297, \mathrm{GV}, 231 \mathrm{a}$} \\
\hline D & \multicolumn{3}{|l|}{$99,173,85$} \\
\hline $\mathrm{E}$ & \multicolumn{3}{|l|}{2} \\
\hline$F$ & \multicolumn{3}{|l|}{$238,114,8,233 b, 125 b$} \\
\hline
\end{tabular}

Volume activity Low $=\left(0.1\right.$ to $\left.7.0 \times 10^{-3} \mathrm{U} / \mathrm{ml}\right)$; Medium $=\left(7.1\right.$ to $\left.17 \times 10^{-3} \mathrm{U} / \mathrm{ml}\right)$; High $=\left(\right.$ above $\left.17 \times 10^{-3} \mathrm{U} / \mathrm{ml}\right) ; A=T$. harzianum / viride; $B=T$. citirinoviride; $C=T$ aureoviride; $D=T$. virens; $E=$ Isolates belonging to Sec. Longibrachiatum; $F=$ Isolates belonging to Sec. Pachybasium. 
Table 5 Preference for chitinase activity (NAGA conc.) on media supplemented with Rhizoctonia cell wall (RCW) and Commercial chitin $(\mathrm{Cc})$ derived colloidal chitin

\begin{tabular}{|c|c|c|}
\hline $\begin{array}{l}\text { Isolate } \\
\text { Group }\end{array}$ & $\begin{array}{l}\text { Low / Medium preference for Cc derived colloidal chitin but } \\
\text { Medium / High preference for RCW derived colloidal chitin }\end{array}$ & $\begin{array}{l}\text { Low / Medium preference for RCW derived colloidal chitin but } \\
\text { Medium / High preference for Cc derived colloidal chitin }\end{array}$ \\
\hline$A$ & $20,32,25,73,120,207,217, \operatorname{Tv}(\mathrm{t})$ & $4,14,20,32,68, \operatorname{Th} 1, \operatorname{Tv}(\mathrm{t})$ \\
\hline B & 24,43 & $24,27,28,29$ \\
\hline $\mathrm{C}$ & $12,38,48,55,62,98,107,249$ 297, 231a & 12, 231a, 297, Gv \\
\hline D & $93,145 b 1,226$ & $85,93,99,173,226,326$ \\
\hline $\mathrm{E}$ & $2,46,53,75,102, \mathrm{Cb} 4$ & 2 \\
\hline $\mathrm{F}$ & 40(1)b, 106, 111, 125b, 204, 233b, 238, 243, 332 & $8,114,125 b, 233 b, 238$ \\
\hline Total & 38 & 26 \\
\hline
\end{tabular}

Trichoderma (Harman et al. 1993; Lorito et al. 1994a; Ulhoa \& Peberdy 1993; De la Cruz et al. 1993; Schickler et al. 1998). Nutrient content of medium is one of the determinant of the levels of lytic enzymes produced and the presence of cell wall material has a significant influence on the production of chitinase by many Trichoderma isolates.

\section{Materials and methods Fungal isolates}

Sixty one Trichoderma isolates from rhizosphere and non rhizosphere soil samples collected from different geographical locations of Chhattisgarh were characterized (as per key identification parameters Gams and Bissets, (Gams \& Bissett 1998)) and maintained in potato dextrose agar (PDA, Himedia) slants in the Department of Plant Molecular Biology \& Biotechnology, IGKV, Raipur, India. Of 61 Trichoderma isolates, 16, 5, 12, 9, 7 and 12 isolates belonged to species groups A (T. harzianum / $T$. viride), B ( $T$. citrinoviride), $\mathbf{C}$ (T. aureoviride), D (T. virens), E (Sec. Longibrachiatum) and F (Sec. Pachybasium) respectively. Rhizoctonia sp. used for colloidal chitin preparation was isolated from the sick soil of the rice field.

\section{Preparation of colloidal chitin}

Colloidal chitin was prepared from Rhizoctonia cell wall and commercial chitin (Himedia) by the method of Roberts and Selitrennikoff (Roberts \& Selitrennikoff 1988) with a few modifications and supplemented in the chitinase assay medium as a sole carbon source. Acid hydrolysis of chitin was done in conc. $\mathrm{HCl}$ by constant stirring using a magnetic stirrer at $4^{\circ} \mathrm{C}$ (refrigerator) overnight, which was followed by extraction of colloidal chitin in $2000 \mathrm{ml}$ of ice-cold 95\% ethanol neutralization kept at $26^{\circ} \mathrm{C}$ for overnight. It was then centrifuge at $3000 \mathrm{rpm}$ for $20 \mathrm{~min}$ at $4^{\circ} \mathrm{C}$. Pellet was washed with sterile distilled water by centrifugation at $3000 \mathrm{rpm}$ for 5 min at $4^{\circ} \mathrm{C}$ till the smell of alcohol was completely removed. The colloidal chitin obtained had a soft, pasty consistency with $90-95 \%$ moisture and was stored at $4^{\circ} \mathrm{C}$ until further use.

\section{Agar medium for detection of chitinase-positive microorganisms}

Chitinase detection medium consisted of a basal medium comprising (per liter) $0.3 \mathrm{~g}$ of $\mathrm{MgSO} 4.7 \mathrm{H} 2 \mathrm{O}, 3.0 \mathrm{~g}$ of $\left(\mathrm{NH}_{4}\right)_{2} \mathrm{SO}_{4}, 2.0 \mathrm{~g}$ of $\mathrm{KH}_{2} \mathrm{PO}_{4}, 1.0 \mathrm{~g}$ of citric acid monohydrate, $15 \mathrm{~g}$ of agar, $200 \mu \mathrm{l}$ of Tween-80, $4.5 \mathrm{~g}$ of colloidal chitin and $0.15 \mathrm{~g}$ of bromocresol purple; $\mathrm{pH}$ was adjusted to 4.7 and then autoclaved at $121^{\circ} \mathrm{C}$ for $15 \mathrm{~min}$. Lukewarm medium was poured in petri-plates and allowed to solidify. Fresh culture plugs of the isolates to be tested for chitinase activity were inoculated into the medium and incubated at $25 \pm 2^{\circ} \mathrm{C}$ and were observed for colored zone formation.

\section{Spectrophotometric determination of chitinase activity of Trichoderma isolates}

Culture plugs containing young actively growing mycelium of Trichoderma isolates were inoculated in colloidal chitin (derived from Rhizoctonia cell wall chitin and commercial chitin) supplemented broth (without bromocresol purple) and incubated at $28^{\circ} \mathrm{C}$ for 5 days at 200 rpm. Cultural filtrates obtained by filtering through Whatman No. 1 filter paper were stored at $-20^{\circ} \mathrm{C}$ until further use. Filtrates were analyzed through spectrophotometric assay was performed for total chitinolytic and $\mathrm{N}$-acetyl- $\beta$-D-glucosaminidase activities.

\section{Total chitinolytic activity}

Total chitinolytic activity was assayed by measuring the release of reducing saccharides from colloidal chitin. A reaction mixture containing $1 \mathrm{ml}$ of culture supernatant, $0.3 \mathrm{ml}$ of $1 \mathrm{M}$ sodium acetate buffer (SA-buffer), $\mathrm{pH} 4.6$ and $0.2 \mathrm{ml}$ of colloidal chitin was incubated at $40^{\circ} \mathrm{C}$ for $20 \mathrm{~h}$ and then centrifuged at 13,000 rpm for $5 \mathrm{~min}$ at $6^{\circ} \mathrm{C}$. After centrifugation, an aliquot of $0.75 \mathrm{ml}$ of the supernatant, $0.25 \mathrm{ml}$ of $1 \%$ solution of dinitrosalycilic acid in $0.7 \mathrm{M} \mathrm{NaOH}$ and $0.1 \mathrm{ml}$ of $10 \mathrm{M} \mathrm{NaOH}$ were mixed in $1.5 \mathrm{ml}$ micro centrifuge tubes and heated at 
$100^{\circ} \mathrm{C}$ for $5 \mathrm{~min}$. Absorbance of the reaction mixture at $A_{582}$ was measured after cooling to room temperature (Miller 1959) Calibration curve with $\mathrm{N}$-acetyl- $\beta-\mathrm{D}$-glucosamine (NAGA) was used as a standard to determine reducing saccharide concentration. Under the assay conditions described, a linear correlation between $A_{582}$ and NAGA concentration was found in the interval of 40$800 \mathrm{mg} / \mathrm{ml}$ NAGA. Chitinolytic activity was estimated in terms of the concentration $(\mathrm{mg} / \mathrm{ml})$ of NAGA released.

\section{Exochitinase activity}

$\mathrm{N}$-acetyl- $\beta$-D-glucosaminidase (exochitinase) activity was measured and monitored spectrophotometrically as the release of $\mathrm{p}$-nitrophenol (pNP) from $\mathrm{p}$-nitrophenyl-Nacetyl- $\beta$-D-glucosaminide (pNPg) A mixture of $25 \mu$ of

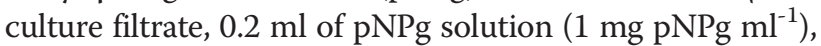
and $1 \mathrm{ml}$ of $0.1 \mathrm{M}$ SA-buffer ( $\mathrm{pH} 4.6$ ) was incubated at $40 \mathrm{C}$ for $20 \mathrm{~h}$ and then centrifuged at $13,000 \mathrm{rpm}$. An aliquot of $0.3 \mathrm{ml}$ of $0.125 \mathrm{M}$ Sodium tetraborate- $\mathrm{NaOH}$ buffer ( $\mathrm{pH} 10.7$ ) was added to $0.6 \mathrm{ml}$ of supernatant, absorbance at $400 \mathrm{~nm}\left(A_{400}\right)$ was measured immediately after mixing and pNP concentration (in terms of Volume Activity) in the solution was calculated using the pNP molar extinction coefficient $\left(18.5 \mathrm{mM}^{-1}-\mathrm{cm}^{-1}\right)$ with the help of following formula:

$$
\begin{aligned}
\text { Volume Activity }(U / m l)= & {[\Delta O D(O D \text { test }-O D \text { blank })} \\
& \left.\times V_{t} \times d f\right] /(18.5 \times t \times \\
& \left.1.0 \times V_{s}\right)
\end{aligned}
$$

where,

$\mathrm{V}_{\mathrm{t}}=$ Total volume $(900 \mu \mathrm{l}) ; \mathrm{Vs}=$ Sample volume $(25 \mu \mathrm{l}) ;$ $18.5=$ Millimolar extinction coefficient of p-nitrophenol under the assay condition $\left(\mathrm{cm}^{2} /\right.$ micromole $) ; 1.0=$ Light path length $(\mathrm{cm}) ; \mathrm{t}=$ Reaction time $(20$ hours $=1200 \mathrm{~min}-$ utes); $\mathrm{df}=$ Dilution factor (Miller 1959).

\section{Competing interests}

The authors declare that they have no competing interests.

\section{Authors' contributions}

TA and ASK equally contributed to the present work. Both authors read and approved the final manuscript.

Received: 21 August 2012 Accepted: 17 December 2012 Published: 20 December 2012

\section{References}

André S, Monika S (2010) Biology and biotechnology of Trichoderma. App Microbiol Biotechnol 87:787-799

Harman GE, Hayes CK, Lorito M, Broadway RM, Di Pietro A, Tronsmo A (1993) Chitinolytic enzymes of Trichoderma harzianum: purification of chitobiosidase and endochitinase. Phytopathol 83:313-318

Samuels GJ (1996) Trichoderma: a review of biology and systematics of the genus. Mycol Res 100:923-935

Spiegel Y, Chet I (1998) Evaluation of Trichoderma spp. as a biocontrol agent against soil borne fungi and plant-parasitic nematodes in Israel. Int Pest Manag Rev 3:169-175

Kubicek CP, Mach RL, Peterbauer CK, Lorito M (2001) Trichoderma: from genes to biocontrol. J Plant Path 83:11-23
Viterbo A, Ramot O, Chemin L, Chet I (2002) Significance of lytic enzymes from Trichoderma spp. in the biocontrol of fungal plant pathogens. Antonie Leeuwenhoek 81:549-556

Benitez T, Rincon AM, Limon MC, Codon AC (2004) Biocontrol mechanisms of Trichoderma strains. Int J Microbiol 7:249-260

Navazio L, Baldan B, Moscatiello R, Zuppini A, Woo SL, Mariani P, Lorito M (2007) Calcium-mediated perception and defense responses activated in plant cells by metabolite mixtures secreted by the biocontrol fungus Trichoderma atroviride. BMC Plant Bio 7:41

Goswami J, Pandey RK, Tewari JP, Goswami BK (2008) Management of root knot nematode on tomato through application of fungal antagonists, Acremonium strictum and Trichoderma harzianum. J Envir Sci Health B 43:237-240

Vinale F, Ghisalberti EL, Sivasithamparam K, Marra R, Ritieni A, Ferracane R, Woo S, Lorito M (2009) Factors affecting the production of Trichoderma harzianum secondary metabolites during the interaction with different plant pathogens. Lett App Microbiol 48:705-711

Karlsson M, Ihrmark K, Asmail N, Ubhayasekera W, Melin P, Stenlid J (2010) Comparative molecular evolution of Trichoderma chitinases in response to mycoparasitic Interactions. Evol Bioinform 6:1-26

Kitamura E, Kamei Y (2003) Molecular cloning, sequencing and expression of the gene encoding a novel chitinase A from marine bacterium, Pseudomonas sp. PE2, and its domain structure. App Microbiol Biotechnol 61:140-149

Markovich NA, Kononova GL (2003) Lytic enzymes of Trichoderma and their role in plant defense from fungal diseases: a review. App Biochem Microbiol 39(4):341-351

Duo-Chuan L (2006) Review of fungal chitinases. Mycopathol 161:345-360

Monreal J, Reese ET (1969) The chitinase of Serratia marcescens. Can J Microbiol 15:669-689

O'Brien M, Collwell RR (1987) A rapid test for chitinase activity that uses 4-methylumbellyferyl-N-acetyl-h-D-glucosaminide. Appl Environ Microbiol 53:1718-1720

McCreath KJ, Gooday GW (1992) A rapid and sensitive micro assay for determination of chitinolytic activity. J Microbiol Methods 14:229-237

Frändberg E, Schnu"rer J (1994) Evaluation of a chromogenic chito-oligosaccharide analogue, p-nitrophenyl-h-D-N,NV-diacetylchitobiose, for the measurement of the chitinolytic activity of bacteria. J Appl Bacteriol 76:259-263

Barboza Corona JE, Contreras JC, Vela'squez Robledo R, Bautista Justo M, Go'mez Ramírez M, Cruz Camarillo R, Ibarra JE (1999) Selection of chitinolytic strains of Bacillus thuringiensis. Biotechnol Lett 21:1125-1129

Agrawal T, Kotasthane AS (2009) A simple medium for screening chitinase activity of Trichoderma spp. In: Methods of Molecular Identification and lab. Protocols. International Subcommission on Trichoderma and Hypocrea Taxonomy (ISTH). http://www.isth.info/methods/method.php?method_id=11

Kamala T, IndiraDevi S (2011) Evaluation of indigenous Trichoderma isolates from Manipur as biocontrol agent against Pythium aphanidermatum on common beans. 3. Biotech 1:217-225

Kamala T, IndiraDevi S (2012) Biocontrol properties of indigenous Trichoderma isolates from North-East India against Fusarium oxysporum and Rhizoctonia solani. Afr J Biotech 11(34):8491-8499

Fen LL, Illias RM, Kamaruddin K, Maskat MY, Hassan O (2006) Development of rapid screening method for low-yielding chitosanase activity using Remazol Brilliant Blue-chitosan as substrate. Enzyme Microbial Technol 38:215-219

Wirth SJ, Wolf GA (1990) Dye-labeled substrates for the assay and detection of chitinase and lysozyme activity. J Microbiol Methods 12:197-205

Cody RM (1989) Distribution of chitinase and chitobiase in Bacillus. Curr Microbiol 19:201-205

Brzezinski R, Mina Z, Melanie F, Jean-Sebastien T (2010) A dye-labeled soluble substrate for the assay of endo-chitosanase activity. Carbo Poly 80:521-524

Vaidya RJ, Macmil SLA, Vyas PR, Chhatpar HS (2003) The novel method for isolating chitinolytic bacteria and its application in screening for hyperchitinase producing mutant of Alcaligenes xylosoxydans. Lett App Microbiol 36:1-6

El-Katatny MH, Somitsch W, Robra KH, El-Katatny MS, Gubitz GM (2000)

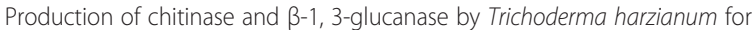
control of the phytopathogenic fungus Sclerotium roflsii. Food Tech Biotechnol 38(3):173-178

Tweddell RJ, Jabaji-Hare SH, Charest PM (1994) Production of chitinases and $\beta-1,3$, glucanases by Stachybotrys elegans, a mycoparasite of $R$. solani. App Env Microbiol 60:489-495

Calistru C, McLean M, Berjak P (1997) In vitro studies on the potential for biological control of Aspergillus flavus and Fusarium moniliforme by 
Trichoderma species. A study of the production of extracellular metabolites by Trichoderma species. Mycopathol 137:115-124

De la Cruz J, Hidalgo-Gallego A, Lora JM, Benítez T, Pintor-Toro JA, Llobell A (1992) Isolation and characterization of three chitinases from

Trichoderma harzianum. Europ J Biochem 206:859-867

Lorito M, Hayes CK, Di Pietro A, Woo SL, Harman GE (1994a) Purification, characterization and synergistic activity of a glucan 1,3- $\beta$-glucosidase and an $\mathrm{N}$ - acetyl- $\beta$-glucosaminidase from Trichoderma harzianum. Phytopath 84:398-405

Sivan A, Chet I (1989) Degradation of fungal cell walls by lytic enzymes of Trichoderma harzianum. J Gen Microbiol 135:675-682

Ulhoa CJ, Peberdy JF (1993) Effect of carbon sources on chitobiase production by Trichoderma harzianum. Mycol Res 97:45-48

De la Cruz J, Rey M, Lora JM, Hidalgo-Gallego A, Domínguez F, Pintor-Toro JA, Llobel A, Benítez T (1993) Carbon source control on $\beta$-glucanases, chitobiase and chitinase from Trichoderma harzianum. Arch Microbiol 159:316-322

Schickler H, Haran S, Oppenheim A, Chet I (1998) Induction of the Trichoderma harzianum chitinolytic system is triggered by the chitin monomer $\mathrm{N}$-acetyl glucosamine. Mycol Res 102:1224-1226

Gams W, Bissett J (1998) Morphology and identification of Trichoderma. In: Harman GE, Kubicek CP (eds) Trichoderma and Gliocladium. Taylor and Francis, London, pp 3-34

Roberts WK, Selitrennikoff CP (1988) Plant and bacterial chitinases differ in antifungal activity. J Gen Microbiol 134:169-176

Miller GL (1959) Use of dinitrosalicylic acid reagent for determination of reducing sugar. Anal Chemistry 31:426-429

Gomez Ramirez M, Rojas Avelizapa LI, Rojas Avelizapa NG, Cruz Camarillo R (2004) Colloidal chitin stained with Remazol Brilliant Blue R, a useful substrate to select chitinolytic microorganisms and to evaluate chitinases. J Microbio Methods 56:213-219

Rojas Avelizapa LI, Go'mez Rami'rez M, Cruz Camarillo R (2001) In: Muzzarelli RAA, Muzzarelli C (eds) Fermentation of shrimp waste to produce proteochitinolytic enzymes and insecticidal crystals. Chitosan in Pharmacy and Chemistry, Atec, Italy, pp 479-487

doi:10.1186/2193-1801-1-73

Cite this article as: Agrawal and Kotasthane: Chitinolytic assay of indigenous Trichoderma isolates collected from different geographical locations of Chhattisgarh in Central India. SpringerPlus 2012 1:73.

\section{Submit your manuscript to a SpringerOpen ${ }^{\circ}$ journal and benefit from:}

- Convenient online submission

- Rigorous peer review

- Immediate publication on acceptance

- Open access: articles freely available online

- High visibility within the field

- Retaining the copyright to your article

Submit your next manuscript at $\gg$ springeropen.com 